\title{
Türkiye'de Belediyelerin Mevcut Kentsel Dönüşüm Uygulamalarına Yönelik Tutumları: İstanbul İlçe Belediyeleri Üzerine Bir Araştırma ${ }^{1}$
}

\author{
Onur Kemal Yilmaz \\ Marmara Üniversitesi
}

\author{
Recep Bozdoğan \\ Marmara Üniversitesi
}

\section{Öz}

Kentsel dönüşüm uygulaması, 1999 Gölcük ve Düzce depremlerinden beri Türkiye'nin ana gündem maddelerinden birisidir. Bu süre zarfinda deprem korkusuna eklenen çarpık kentleşme ve dönüşümden elde edilen rant olgusuyla birlikte, kentsel dönüşümün bir milli seferberlik halinde uygulandı̆̆ın söylemek yanlı̧ olmayacaktır. Fakat daha öncesinden tecrübe edilmemiş uygulamaları bir anda hayata geçirilmesi, kentsel dönüşüm adına nitelik sorgulamasını da beraberinde getirmektedir. Konuyla ilgili olarak bu çalışmayla, Türkiye ölçeğinde kentsel dönüşümün en önemli uygulayıcıs olan belediyelerin, mevcut kentsel dönüşüm uygulamalarmın niteliklerine yönelik tutumlar öğrenilmeye çalışllmıştır. Burada belediyelerin seçilme gerekçesi; belediyelerin kentleri imar etmek, geliştirmek ve kentsel dönüşüme tabi tutmak üzere en üst seviyede yetkilendirilmiş kurumlar olmalarıdır. Ayrıca literatür taraması sırasında, Türkiye ölçeğinde kentsel dönüşüm uygulamalarmın niteliklerini ölçmek için belediyelerin görüşlerine şimdiye kadar başvurulmadığ tespit edilmiştir. Çalışma kapsamında, İstanbul metropolünde faaliyet gösteren 39 belediyede görevli 77 müdüre ulaşılmıştır. Anket yöntemi kullanılarak gerçekleştirilen araştırmanın sonuçları SPSS istatistik programının güvenilirlik analizine tabi tutulmuş ve oran 0,97 çıkmıştır. Bu kapsamda güvenilirliği kanıtlanmış olan sorularla elde edilen verilere bakıldığında; Türkiye ölçeğinde uygulanan kentsel dönüşüm çalışmalarının fiziksel, ekonomik, sosyal, planlama, yönetişim ve hukuki boyutlarında belediyeler açısından olumsuzluklar görüldü̈̆̈̈ tespit edilmiştir.

Anahtar Kelimeler: Kentsel dönüşüm, sosyal boyut, fiziksel boyut, ekonomik boyut, yönetişim boyutu.

\footnotetext{
${ }^{1}$ Bu çalışma yazarın (Onur Kemal Y1lmaz) doktora tezinden üretilmiştir. Doktora tezinin danışmanlığını diğer yazar (Prof. Dr. Recep Bozdoğan) gerçekleştirmiştir.

idealkent @ Kent Araştırmaları Dergisi (Journal of Urban Studies) 


\title{
Attitudes of The Municipalities to the Existing Urban Transformation Works in Turkey: A Research Through Istanbul County Municipalities
}

\author{
Onur Kemal Yilmaz \\ Marmara University
}

\author{
Recep Bozdoğan \\ Marmara University
}

\begin{abstract}
Urban transformation is one of Turkey's main agenda since the 1999 Gölcük and Düzce earthquakes. Over time, urbanization problems and rent are added to this fear of earthquake. So it would not be wrong to say that urban transformation has been implemented as a national mobilization. But unprecedented practices have brought questions about the quality of urban transformation which are implemented in Turkey. In relation to the subject, with this study; the views of the municipalities on the existing urban transformation works have been identified. Reason for choosing the municipalities is; the municipalities are the most important urban transformation practitioners in Turkey. In addition, during the literature review it was seen that the attitudes of the municipalities were not identified in relation to the urban transformation studies in Turkey. Within the scope of the study, 77 managers who are serving in 39 municipalities in Istanbul were reached. The results were subjected to reliability analysis of the SPSS statistical program and the ratio was 0.97. In this context, it has been determined that there are problems at physical, economic, social, planning, governance and legal dimensions of urban transformation works in terms of municipalities.
\end{abstract}

Keywords: Urban transformation, social dimension, physical dimension, economic dimension, governance dimension. 


\section{Giriş}

Dünya genelinde kentsel dönüşümün bir ihtiyaç haline gelişi 1750'lerde Sanayi Devrimiyle birlikte başlamıştır. Bu dönemde kırdan kente doğru yaşanan plansız göçler, endüstriye ev sahipliği yapan şehirlerde aşırı derecede nüfus artışına sebebiyet vermiş, bunun sonucunda da çarpık kentleşme ve sağlıksız yaşam alanları büyük kentleri adeta kuşatmışlardı (Couch, 1990, ss. 1-11). Bu tarihten sonra ortaya konulan kentsel dönüşüm müdahaleleriyle kentlerin fiziksel, ekonomik ve sosyal sorunlarına çözümler getirilmeye çalışılmıştır. Bu uygulamalar ilk başta Sanayi Devrimini yaşayan ülkelerde ortaya konulduklarından dolayı, kentsel dönüşümün gelişmiş ülkelerde meydana geldiğini ve şekillendiğini söylemek doğru olacaktır. Bu kapsamda sanayi kentlerinde yeşil alan miktarını arttırmayı hedefleyen "kentsel park hareketi" (Urban Park Movement) ile 1840'larda başlayan kentlere müdahale edilmesi anlayışı, daha sonraları gelişerek devam etmiştir. (Loures, Santos ve Panagopoulus, 2007, s. 171; Akkar, 2006, ss. 30). 1850'lerde Paris'te Baron Haussmann tarafından büyük bir kentsel dönüşüm hamlesi başlatılmıştı. Bu çalışmalarda kent içerisinde eski yapılar yıkılırken; geniş bulvarların yapımı, kamu binalarının yeniden inşası ve konutların da yenilenmeleri gerçekleştirilmiştir. Avrupa'da yaygınlaşan bu kente müdahale anlayışı Amerika Birleşik Devletleri'nde (A.B.D.) "güzel kent hareketi" (City Beautiful Movement) olarak karşlık bulmuştur. Böylece A.B.D.'de de kentsel ölçekte kente müdahale edilmesi gelişim göstermiştir. Bu güzel kent hareketinin en önemli uygulamaları Kuzey Amerika'da gerçekleştirilmiştir. Daha sonraki süreçte Ebenzer Howard tarafından "bahçe kent" (Garden City) vizyonu ortaya konularak, kentlerin daha küçük ölçekli ve doğal çevreyle bütünleşik olarak "kır-kent" senteziyle üretilmeleri gerektiği hem akademik seviyede dile getirilmiş hem de fiili olarak bazı örneklerle uygulanmıştır (Akkar, 2006, ss. 3031). Bu uygulamalara örnek olarak Londra'da yer alan 1903 tarihli Letchworth Bahçe Kenti gösterilebilir.

Bu yıllarda ayrıca kentsel dönüşümle ilgili olarak İşçi Sınıfına Konut Sağlanması Kanunu (The Housing of the Working Classes Act 1890) 1890 yılında İngiltere'de ve Konut Kanunu (Housing Act 1937) 1937 yllında A.B.D.'de uygulamaya konulmuştur. Böylece bu kanunlarla, özellikle yerel otoriteler üzerinden sağlıksız yaşam alanlarının kentlerden uzaklaştıılması hedeflenmiştir ve alansal temizleme (slum clearance) uygulaması yaygın hale gelmiştir. $\mathrm{Bu}$ kapsamda artık kentlerde gecekondu gibi sefalet yuvalarının temizlen- 
mesi hız kazanmıştır. İlerleyen dönemlerde kentsel dönüşüm kendi içerisinde hızla yeni uygulamalara ev sahipliği yapmaya başlamıştır. Dolayısıyla her yeni gelen dönem kendi durumuna göre yeni kentsel dönüşüm uygulamalarının meydana gelmesini sağlamıştır. Bu süreçte 2. Dünya Savaşı sonrası boşalan kentlerin canlandırılması için kente yapılan müdahaleler dikkat çekmektedir. Eski canlılığını yitiren ve çöküntü hale gelen kentlerin yeniden canlandırılmasını hedefleyen kentsel canlandırma (urban revitalisation) uygulaması bunlardan birisidir (Oruç ve Giritlioğlu, 2008, s. 98). İlerleyen yıllarda özellikle 1950'lerden sonra, ekonomik gelişime paralel olarak değişen sosyal yapıya uygun olarak kentlerin yenilenmesi gündeme gelmiştir. Bu süreçte yapıların yenilenmesini öngören kentsel yenileme (urban renewal) uygulaması en çok başvurulan yöntem olmuştur. Böylece eski yapıların yıkılmaları ve yeniden inşa edilmeleri yaygınlaşmıştır. Son olarak 1990'larla birlikte kentlerin daha bütüncül yaklaşımlarla geliştirilmesini amaçlayan yeniden üretim (urban regeneration) yöntemi önemli bir kente müdahale aracı olarak işlev görmüştür. Bu uygulamada özel sektörün ön plana çıkmasıyla, ekonomik gelişim de kentsel dönüşüm bölgelerinde sağlanmıştır (Roberts ve Sykes, 2008, s. 14).

Konuya Türkiye özelinde bakılacak olursa, gelişmiş ülkelerdeki gibi bir Sanayi Devrimi yaşamayan Türkiye' de kentsel dönüşümün bilinirliğinin artması ve önemli bir kente müdahale aracı olarak kullanılması, 1999 yılında yaşanan Gölcük ve Düzce depremleriyle olmuştur. Dolayısıyla kentsel dönüşüm kavramının Türkiye'de kamu nezdinde mevzuatlarla geliştirilmesi ve kurumsallaşması gelişmiş ülkelerden yaklaşık 150 yıl sonra gerçekleşmiştir. Bu tarihten sonra, bilimsel temellerde inşa edilmemiş yapıların insanların can güvenliğini sağlamak önceliğinde yenilenmeleri temel bir ülke politikasına dönüşmüştür. Bunun yanında çarpık kentleşme ve dönüşümden elde edilen rant olgusu da Türkiye ölçeğinde kentsel dönüşümün gerekçelerini oluşturmaktadırlar. Bütün bu bileşenler göz önüne alındığında, Türkiye'de kentsel dönüşümün son 20 yıldır bir milli seferberlik halinde gerçekleştirildiğini söylemek yanlış olmayacaktır. Fakat bu durum mevcut kentsel dönüşüm uygulamalarının niteliklerinde sorunları da beraberinde getirmektedir. Bunun sebebi; daha öncesinden gelişmiş ülkelerde olduğu gibi uzun bir zaman diliminde tecrübe edilmemiş, güncellenmemiş ve geliştirilmemiş uygulamaların bir anda hayata geçirilmesidir. Konuyla ilgili olarak bu çalışmayla amaçlanan da Türkiye ölçeğinde gerçekleştirilen bu yoğun kentsel dönüşüm uygulamalarının niteliklerini irdelemektir. 
Her ülkenin ve kentin kentleşme süreci farklı olduğundan, gerçekleştirilen kentsel dönüşüm uygulamaları da değişkenlik göstermektedir. Bu durumun temelinde kentsel dönüşüm uygulanan ülkelerde yaşayan insanların kültürleri, sosyal yapıları ve ekonomik durumları etkili olmaktadır. Fakat kentsel dönüşümden beklenen kentlerin sorunlarını çözmek olduğu için, kentsel dönüşüm uygulamalarınn niteliklerini ölçmek bir çalışma alanı olarak görülebilir. Burada önemli olan nokta, kentsel dönüşüm uygulamalarının niteliklerine yönelik durumun, ülkelerin kendi özelinde irdelenmesi gerektiğidir. Bu kapsamda, bu çalışma ile Türkiye ölçeğindeki kentsel dönüşüm uygulamalarının nitelikleri belediyelerin bakış açısıyla tespit edilmeye çalışılmıştır. Burada amaçlanan; Türkiye'de kentleri imar etmek, geliştirmek ve kentsel dönüşüme tabi tutmak üzere yetkilendirilmiş olan belediyelerin, mevcut kentsel dönüşüm uygulamalarının niteliklerine yönelik olan tutumlarını tespit etmektir. Böylece Türkiye ölçeğinde uygulanan kentsel dönüşümün, halkın bakış açısından farklı olarak daha teknik ve aynı zamanda uygulayıc bir aktör tarafından değerlendirilmesi amaçlanmıştır.

Bu kapsamda çalışma ile yanıt aranan sorular şu şekildedir;

1. Belediyeler, imar etmeleri ve geliştirmeleri için yetkilendirildikleri bir kentte, kentsel dönüşüm alanında başka aktörlerin çalışma yapmasına hangi oranda olumlu bakmaktadırlar?

2. Belediyeler, kentsel dönüşüm konusunda diğer aktörlerin çalışmalarını ne oranda etkin bulmaktadırlar?

3. Belediyeler açısından mevcut kentsel dönüşüm uygulamalarının sosyal boyutunda ne oranda etkinlik sağlanabilmektedir?

4. Belediyeler açısından mevcut kentsel dönüşüm uygulamalarının fiziksel boyutunda ne oranda etkinlik sağlanabilmektedir?

5. Belediyeler açısından mevcut kentsel dönüşüm uygulamalarının ekonomik boyutunda ne oranda etkinlik sağlanabilmektedir?

6. Belediyeler açısından mevcut kentsel dönüşüm uygulamalarının planlama boyutunda ne oranda etkinlik sağlanabilmektedir?

7. Belediyeler açısından mevcut kentsel dönüşüm uygulamalarının yönetişim boyutunda ne oranda etkinlik sağlanabilmektedir?

8. Belediyeler açısından mevcut kentsel dönüşüm uygulamalarının hukuki boyutunda ne oranda etkinlik sağlanabilmektedir? 


\section{Araştırma Evreni ve Araştırma Yöntemi}

Araştırma evrenini İstanbul metropolünde mevcut olan ilçe belediyeleri oluşturmaktadır. Evrenin bu belediyelerden oluşmasının sebebi; Türkiye'de kentsel dönüşüm çalışmalarının en yoğun olarak İstanbul'da gerçekleştirilmesidir. Ayrıca siyasi bir yanı da olan konuyla ilgili olarak, İstanbul hem iktidar hem de muhalefet partisine mensup belediyelerin nispeten dengeli bir sayıda temsilini sağlamaktadır. Çalışmaya bu belediyelerde bulunan ve kentsel dönüşüm uygulamalarına doğrudan veya dolaylı olarak etki eden müdürlükler dâhil edilmiştir. Bu kapsamda örneklemi oluşturan müdürlükler şu şekildedir; yapı kontrol müdürlükleri, plan ve proje müdürlükleri, kentsel estetik müdürlükleri, kentsel dönüşüm müdürlükleri, fen işleri müdürlükleri ve imar ve şehircilik müdürlükleri. Belediye ve Bağlı Kuruluşları İle Mahalli İdare Birlikleri Norm Kadro İlke ve Standartlarına Dair Yönetmelik'in ek maddesinde yer alan açıklamaya göre, tüm belediyelerde fen işleri ve imar ve şehircilik müdürlükleri zorunlu birimler olup; belediyeler nüfuslarına göre eğer isterlerse bünyelerinde diğer müdürlükleri de oluşturabilmektedirler. Bu kapsamda 39 belediyenin internet sitesi ayrı ayrı incelenmiş ve çalışmaya dâhil edilebilecek 144 müdürlük tespit edilmiştir.

Çalışma kapsamında saha araştırması yapılması için anket yöntemi kullanılmıştır. Anket çalışması da "tarama modeli" dikkate alınarak oluşturulmuştur. Karasar'ın belirttiğine göre tarama modeli; geçmişte mevcut olan veya güncel durumda halen varlığı devam eden bir durumu, mevcut haliyle açıklamayı amaçlayan bir modeldir. Burada araştırmaya konu olan kişi, kurum veya olay kendi özel şartlarında betimlenmeye çalışılmaktadır (Karasar, 2012, s. 77). Tarama modelinin alt bileşenlerinden birisi "tümevarım" yaklaşımıdır. Teori ve uygulama yönünden sınırlı bilgi düzeyine sahip olunduğu durumlarda, ayrıca konuyla ilgili genel ilkelerin henüz kesinleşmediği koşullarda bu tümevarım yaklaşımı kullanılabilmektedir (Bozlağan, 2005, s. 78). Bu araştırma kapsamında yapılan yerli ve yabancı literatür taraması sırasında, belediyelerin bakış açısıyla kentsel dönüşüm uygulamalarının niteliklerini ölçen bir çalışmaya rastlanmadığından dolayı tümevarım yöntemi; diğer bir ifade ile keşfe yönelik ve mevcut durumu tespit eden yöntem kullanılmıştır.

İstanbul metropolünün büyüklüğü ve çalışma yapılacak olan denek sayısının çokluğundan dolayı, enerji ve zaman yönetimini sağlamak adına an- 
ket soruları internet üzerinden çevrimiçi oluşturulmuştur. Anket sorularının bu müdürlüklere ulaştırılması için Marmara Üniversitesi Rektörlüğü ile gerekli yazışmalar yapılmış ve internet üzerinden çevrimiçi olarak oluşturulmuş anket sorularına ilişkin internet adresi; bilimsel araştırma kapsamında Rektörlük tarafından 39 ilçe belediyesine resmi yazıyla ulaştırılmıştır. Bu anket sorularına internet üzerinden üçüncü kişilerin ulaşımını engellemek için her müdürlük adına bir giriş şifresi oluşturulmuş ve bu giriş kodları da belediyelere ulaştırılmıştır. Böylece internet üzerinden oluşturulmuş ankete üçüncü kişilerin erişimi engellenmiştir.

Konuyla ilgili olarak daha öncesinden hazırlanan, test edilen ve uygulanan bir anket çalışması olmadığından dolayı yeni bir anket formunun hazırlanması gerekmiştir. Anket sorularının hazırlanması için yerli ve yabancı kaynaklardan yararlanılmıştır. Faydalanılan kaynaklar şu şekildedir;

1. Kentsel Dönüşüm Uygulamalarına Çok Amaçlı Yaklaşım, Bursa (İnegöl) Kent Örneği (Aslı Bozdağ, Şaban İnam, Savaş Durduran)

2. Kentsel Dönüşümü Gündeme Gelen Bir Alan İçin Konut Memnuniyeti Araştırması: Türk-İş Blokları Örneği (Zerrin Ezgi Kahraman, Suna Senem Özdemir)

3. Kentsel Dönüşüm Yaklaşımında Kullanıcı Memnuniyet Analizi (Demet Aykal, Özgür Murat, Mahir Korkmaz, Bahar Acar)

4. Kentsel Dönüşüm Anket Çalışması. (TMMOB İzmir İl Koordinasyon Kurulu)

5. Kentsel Dönüşümde Riskler ve Beklentilere Dair İlk Tespitler: İstanbul'da Bir Saha Araştırması (Betül Duman)

6. Kentsel Dönüşüm Sürecinde TOKİ Uygulamaları ve Halkın Algılarına Göre Değerlendirilmesi (Halil İbrahim Alpaslan ve Abdullah Tüter)

7. Türkiye'de Kentleşme Projelerinde Yerel Yönetimlerin Rolü ve Bu Projelerin Kentlileşmeye Etkisi: Kars Örneği (Abdulsamet Yaman, Cihan Arslan ve Gökbörü Önalp)

8. Şehirlerin Fiziki Modernizasyonu: Çorum Uygulaması (Rıdvan Keskin ve Ömür Demirer)

9. Yavuzlar (Yüreğir-Adana) Mahallesi Kentsel Dönüşümü İle TOKİ Konutlarının Karşılaştırmalı Analizi (Tülay Öcal ve Vedat Çelik)

10. Measuring Social Sustainable Urban Regeneration in Europa (Andrea Colantonio ve Tim Dixon)

11. Criteria For a "Good" Urban Renewal Project: The Case Of Kadifekale Urban Renewal Project (Elif Mutlu) 
12. Effective Approach to Achieve Sustainable Urban Renewal In Densely Populated Cities (Grace Lee ve Edwin Chan)

13. Sürdürülebilir Kentsel Dönüşüm İçin Performans Göstergeleri (Aslı Ulubaş Hamurcu ve Mesture Aysan Buldurur)

14. Resident Satisfaction for Sustainable Urban Regeneration (Yasemin Afacan)

\section{Çalışmanın Güvenilirliği}

Anket çalışması Mayıs 2018 tarihinde gerçekleştirilmiş olup, örneklemi oluşturan 144 müdürden 77 tanesi çalışmaya katılım göstermiştir. Çalışma kapsamında elde edilen veriler SPSS veri analiz programının 22. Sürümünde Cronbach's Alfa güvenilirlik analizine tabi tutulmuş, çıkan sonuç 0.97 olmuştur. Kaya'nın belirttiğine göre, Cronbach's Alpha güvenilirlik değeri için 0.70 ve üzer oldukça güvenilir bir değerdir (Kaya, 2013, s. 185). Bu kapsamda güvenilirlik analizinden çıkan yüksek sonuç, bu soruların başka belediyeler üzerinde de kullanılabileceğini göstermektedir.

\section{Araştırmanın Bulguları}

Anket çalışmasıyla elde edilen veriler aşağıda tablolar halinde sunulmuştur. Tablolarda ayrıca ortalama değer (mean) de belirtilmiştir. Ortalama değerle kastedilen; düşük seviyedeki değer önermeye verilen yanıtların olumsuzluk içerdiğini, yüksek seviyedeki değer ise önermeye olumlu yanıtların verildiğini ifade etmektedir. Tablolarda gösterilen düşük düzeydeki standart sapma ise; cevapların belirli bir aralıkta dağıldığını, dolayısıyla yanıtlar arasında tutarlılığın yüksek olduğunu göstermektedir. Anket uygulaması sırasında, anketin en başında şu şekilde bir ibare yer almıştır: "Önermeleri şu cümlenin devamı olarak okuyunuz; "mevcut kentsel dönüşüm uygulamalarında". Dolayısıyla tablolardaki önermeler bu cümle temelinde değerlendirilmelidirler. Tablo altında yapılan açıklamalarda "kesinlikle katılmıyorum" ve "katılmiyorum" yanıtları birlikte değerlendirilirken, "katılıyorum" ve "kesinlikle katılıyorum" yanıtları da birlikte değerlendirilmiştir. 
Tablo 1. Aktörlere yönelik önermeler.

\begin{tabular}{|c|c|c|c|c|c|c|c|c|c|c|c|c|}
\hline \multirow[t]{2}{*}{ Önermeler } & \multicolumn{2}{|c|}{$\begin{array}{l}\text { Kesinlikle } \\
\text { Katılmiyo- } \\
\text { rum }\end{array}$} & \multicolumn{2}{|c|}{$\begin{array}{l}\text { Katılmiyo- } \\
\text { rum }\end{array}$} & \multicolumn{2}{|c|}{$\begin{array}{l}\text { Ne Katıl1- } \\
\text { yorum Ne } \\
\text { Katılmiyo- } \\
\text { rum }\end{array}$} & \multicolumn{2}{|c|}{$\begin{array}{l}\text { Katıliyo- } \\
\text { rum }\end{array}$} & \multicolumn{2}{|c|}{$\begin{array}{l}\text { Kesinlikle } \\
\text { Katıliyo- } \\
\text { rum }\end{array}$} & \multirow[t]{2}{*}{$\begin{array}{l}\text { Orta- } \\
\text { lama } \\
\text { (Mean) }\end{array}$} & \multirow[t]{2}{*}{$\begin{array}{l}\text { Stan- } \\
\text { dart } \\
\text { Sapma }\end{array}$} \\
\hline & $\mathrm{n}$ & $\%$ & $\mathrm{n}$ & $\%$ & $\mathrm{n}$ & $\%$ & $\mathrm{n}$ & $\%$ & $\mathrm{n}$ & $\%$ & & \\
\hline $\begin{array}{l}\text { 1.1. TOKİ'nin belediyelerden ba- } \\
\text { ğımsız olarak kentsel dönüşüm } \\
\text { gerçekleştirme yetkisine sahip } \\
\text { olması doğru bir uygulamadır. }\end{array}$ & 17 & 22,1 & 37 & 48,1 & 8 & 10,4 & 10 & 13 & 5 & 6,4 & 2,338 & 1,1541 \\
\hline $\begin{array}{l}\text { 1.2. Mülk sahiplerinin } 6306 \text { sa- } \\
\text { yılı Kanun kapsamında yapıla- } \\
\text { rını belediyelerden bağımsız } \\
\text { olarak yenilemeleri doğru bir } \\
\text { uygulamadır. }\end{array}$ & 17 & 22,1 & 28 & 36,4 & 14 & 18,2 & 14 & 18,2 & 4 & 5,1 & 2,481 & 1,1766 \\
\hline $\begin{array}{l}\text { 1.3. Çevre ve Şehircilik Bakanlı- } \\
\text { ğı'nın belediyelerden bağımsız } \\
\text { olarak riskli alan ilan etme yet- } \\
\text { kisine sahip olması doğru bir } \\
\text { uygulamadır. }\end{array}$ & 12 & 15,6 & 33 & 42,9 & 10 & 13 & 19 & 24,7 & 3 & 3,8 & 2,584 & 1,1396 \\
\hline $\begin{array}{l}\text { 1.4. TOKİ, kentsel dönüşüm ça- } \\
\text { lışmaları yaparken belediyeler } \\
\text { tarafından hazırlanan mevcut } \\
\text { imar planlarını yeterli ölçüde } \\
\text { dikkate almaktadır. }\end{array}$ & 10 & 13 & 35 & 45,5 & 14 & 18,2 & 18 & 23,3 & 0 & 0 & 2,519 & 0,9949 \\
\hline $\begin{array}{l}\text { 1.5. Çevre ve Şehircilik Bakan- } \\
\text { lığı kentsel dönüşüm çalışmaları } \\
\text { yaparken, belediyeler tarafından } \\
\text { hazırlanan mevcut imar planla- } \\
\text { rını yeterli ölçüde dikkate al- } \\
\text { maktadır. }\end{array}$ & 12 & 15,6 & 33 & 42,9 & 12 & 15,5 & 20 & 26 & 0 & 0 & 2,519 & 1,0464 \\
\hline $\begin{array}{l}\text { 1.6. TOKİ tarafından üretilen ya- } \\
\text { pılar, kentin mevcut kimliğini } \\
\text { ve estetiğini yansıtmaktadırlar. }\end{array}$ & 23 & 29,9 & 27 & 35,1 & 18 & 23,4 & 8 & 10,4 & 1 & 1,2 & 2,182 & 1,0225 \\
\hline $\begin{array}{l}\text { 1.7. TOKİ ve Çevre ve Şehircilik } \\
\text { Bakanlığının kentsel dönüşüm } \\
\text { konusundaki yetkileri belediye- } \\
\text { lere aktarılmalıdır. }\end{array}$ & 8 & 10,4 & 16 & 20,8 & 22 & 28,6 & 24 & 31,1 & 7 & 9,1 & 3,078 & 1,1444 \\
\hline
\end{tabular}

Belediyeler açısından, TOKİ'nin kendi başına kentsel dönüşüm kararı alma yetkisine sahip olmasına \%70,2 oranında olumsuz bakılmaktadır [Bkz. Önerme 1.1.]. Çevre ve Şehircilik Bakanlığ (ÇŞB) ve mülk sahipleri konusunda bu oran \%58,5 düzeyindedir [Bkz. Önerme 1.2. ve 1.3.]. Belediyeler; ÇŞB ve TOKİ tarafından uygulanan dönüşüm çalışmalarının, kentin mevcut imar düzenini bozduğunu $\% 58,5$ oranında dile getirmektedirler [Bkz. Önerme 1.4. ve 1.5.]. TOKİ tarafından imar edilen yapıların kentin mevcut estetiğini ve kimliğini bozduğunu belirtenlerin oranı ise \%65 ile oldukça yüksek çıkmıştır [Bkz. Önerme 1.6.]. Son olarak aktörler kapsamında, ÇŞB ve TOKİ'nin sahip oldukları kentsel dönüşüm yetkilerinin 
belediyelere devredilmesi önermesine \%40,2 oranında olumlu görüş belirtilmiş; olumsuz görüş belirtenlerin oranı ise $\% 31,2$ ile azınlıkta kalmıştır [Bkz. Önerme 1.7.].

Tablo 2. Fiziksel boyuta yönelik önermeler.

\begin{tabular}{|c|c|c|c|c|c|c|c|}
\hline Önermeler & $\begin{array}{c}\text { Kesinlikle } \\
\text { Katılmıyo- } \\
\text { rum }\end{array}$ & $\begin{array}{l}\text { Katılmiyo- } \\
\text { rum }\end{array}$ & $\begin{array}{c}\text { Ne Katıl1- } \\
\text { - yorum Ne } \\
\text { Katılmiyo- } \\
\text { rum }\end{array}$ & $\begin{array}{l}\text { Katıliyo- } \\
\text { rum }\end{array}$ & $\begin{array}{c}\text { Kesin- } \\
\text { likle } \\
\text { Katılı- } \\
\text { yorum }\end{array}$ & $\begin{array}{c}\text { Orta- } \\
\text { lama } \\
\text { (Mean) }\end{array}$ & $\begin{array}{c}\text { Stan- } \\
\text { dart } \\
\text { Sapma }\end{array}$ \\
\hline
\end{tabular}

2.8. Yeterli sayıda sağlık ku-

$\begin{array}{lllllllllllll}\text { rumları (hastane, sağlık ocağı, } & 6 & 7,8 & 33 & 42,9 & 16 & 20,8 & 21 & 27,3 & 1 & 1,3 & 2,714 & 0,9981\end{array}$ aile hekimliği) üretilmektedir.

2.9. Çocuklar ve gençler için yeterli oyun ve spor alanları (futbol sahası, basketbol sahası, oyun parkı vd.) üretilmektedir.

2.10. Yenilenebilir enerji kaynaklarının (rüzgâr, su, güneş vd.) kullanımı yaygınlaştırıl$\begin{array}{llllllllllll}14 & 18,2 & 27 & 35,1 & 10 & 13 & 22 & 28,6 & 4 & 5,2 & 2,675 & 1,2187\end{array}$ maktadır.

2.11. Atıkların geri dönüşümünü mümkün kılacak çözüm- $\quad \begin{array}{llllllllllll}17 & 22,1 & 30 & 39 & 14 & 18,2 & 12 & 15,6 & 4 & 5,2 & 2,429 & 1,152\end{array}$ ler üretilmektedir.

2.12. Yaşlılar için yeterli alanlar (dinlenme, yürüyüş vd.) üretil- $\quad \begin{array}{llllllllllll}14 & 18,2 & 31 & 40,3 & 15 & 19,5 & 12 & 15,6 & 5 & 6,5 & 2,519 & 1,1541\end{array}$ mektedir. 
Tablo 2. Fiziksel boyuta yönelik önermeler. (devam)

\begin{tabular}{|c|c|c|c|c|c|c|c|c|c|c|c|c|}
\hline $\begin{array}{l}\text { 2.13. Dönüşüm uygulanan yer- } \\
\text { lerde nüfus ve yapı yoğunluğu } \\
\text { kontrol altında tutulmaktadır. }\end{array}$ & 19 & 24,7 & 33 & 42,9 & 13 & 16,9 & 10 & 13 & 2 & 2,6 & 2,261 & 1,0563 \\
\hline $\begin{array}{l}\text { 2.14. Doğal ve ekolojik çevre ile } \\
\text { uyumlu bir kent dokusu oluş- } \\
\text { turulmaktadır. }\end{array}$ & 23 & 29,9 & 29 & 37,7 & 15 & 19,5 & 10 & 13 & 0 & 0 & 2,156 & 1,0009 \\
\hline $\begin{array}{l}\text { 2.15. Yeni yapılar, tarihsel sü- } \\
\text { reçte meydana gelmiş olan } \\
\text { kentsel estetiğe uygun üretil- } \\
\text { mektedirler. }\end{array}$ & 18 & 23,4 & 40 & 51,9 & 13 & 16,9 & 6 & 7,8 & 0 & 0 & 2,091 & 0,8458 \\
\hline $\begin{array}{l}\text { 2.16. Hava, su ve gürültü kirliği } \\
\text { kontrol altında tutulmaktadır. }\end{array}$ & 20 & 26 & 31 & 40,3 & 16 & 20,8 & 8 & 10,4 & 2 & 2,6 & 2,234 & 1,0374 \\
\hline
\end{tabular}

Belediyeler, kentsel dönüşüm uygulamaları sırasında altyapı sisteminin (şebeke suyu, kanalizasyon, yağmur drenajı, vd.) bölgenin ihtiyaçlarını karşılayacak seviyede geliştirildiğini \%49,4 oranında düşünmektedirler (olumsuz bakanların oranı \%36,4'tür) [Bkz. Önerme 2.1.]. Fakat dönüşüm çalışmaları sırasında ulaşım altyapısının (araç yolları, kaldırımlar, yaya yolları, oto parklar, vd.) yeterli seviyede geliştirilmediğini düşünenlerin oranı \%44,2' dir (olumlu bakanların oranı \%39) [Bkz. Önerme 2.2.]. Kentsel dönüşüm çalışmaları sırasında yeterli seviyede yeşil alan üretilmediğini düşünenlerin oranı \%63,7 ile yüksek çıkmıştır [Bkz. Önerme 2.3.]. Dönüşüm çalışmaları sırasında kentin tarihi kimliğinin korunmad1ğını düşünenlerin oranı da \%57,2'dir [Bkz. Önerme 2.4.]. Kentsel dönüşüm çalışmalarıyla üretilen yeni yapıların afetlere karşı yeterli seviyede dayanıklılığa sahip olduğunu belirtenlerin oranı ise \%57,1'dir [Bkz. Önerme 2.5.]. Yeni inşa edilen yapılarda güncel materyaller ve teknikler kullanıldığı için, bu önermeye yüksek oranda olumlu bakılması anlaşılabilir bir durumdur.

Belediyelere göre fiziksel bakımdan mevcut kentsel dönüşüm uygulamalarında, kent \%23,4 oranında engellilere uygun hale getirilmektedir [Bkz. Önerme 2.6.]. Bu rakam engelliler açısından oldukça yetersiz bir durumu tespit etmektedir. Kentsel dönüşüm çalışmalarıyla yeterli sayıda kültür ve sanat mekânı (tiyatro, müze, sanat galerisi, sinema, gösteri merkezi) üretilmediğini belirtenlerin oranı \%55,9 [Bkz. Önerme 2.7.]; yeterli sayıda sağlık kurumu (sağlık ocağı, aile hekimliği, hastane) üretilmediğini belirtenlerin oranı \%50,7 [Bkz. Önerme 2.8.]; yaşlılar için yeterli alan (yürüme, toplanma, dinlenme) üretilmediğini belirtenlerin oranı \%58,5 [Bkz. Önerme 2.12.]; gençler için spor ve oyun alanı üretilmediğini belirtenlerin 
oranı da \%44,2 olmuştur [Bkz. Önerme 2.9.]. Bu rakamlar kentsel dönüşümle daha çok konutlar üzerine çalışmalar yapıldığını, diğer mekânsal donatılara yeterli önceliğin verilmediğini göstermektedir.

Belediyeler açısından mevcut kentsel dönüşüm uygulamalarında, yenilenebilir enerji kaynaklarının (rüzgâr, güneş, su) yaygınlaştırılmadığını düşünenlerin oranı \%53,3’tür [Bkz. Önerme2.10.]. Atıkların geri dönüşümünü mümkün kılacak tesislerin geliştirilmediğini düşünenlerin oranı ise \%61,1'dir [Bkz. Önerme 2.11.]. Kentsel dönüşüm çalışmaları sırasında nüfus ve konut yoğunluğunun makul seviyelerde tutulamadığını belirtenlerin oranı \%67,6 ile yüksek bir değerdedir [Bkz. Önerme 2.13.]. Uygulamalarda doğal ve ekolojik çevreye uyumlu bir yapılaşma geliştirilmediğini söyleyenlerin oranı \%67,6' dır [Bkz. Önerme 2.14.]. Bu çalışmalarda kentin mevcut estetik değerleriyle uyumsuz yapılar üretildiğini belirtenlerin oranı \%75,3'tür [Bkz. Önerme 2.15.]. Bunlara ilave olarak, kentsel dönüşüm yapılan alanlarda gürültü, hava ve su kirliliğinin kontrol altına alınamadığını dile getirenlerin oranı da \%66,3 olmuştur [Bkz. Önerme 2.16.].

Tablo 3. Sosyal boyuta yönelik önermeler.

\begin{tabular}{|c|c|c|c|c|c|c|c|c|c|c|c|c|}
\hline \multirow[t]{2}{*}{ Önermeler } & \multicolumn{2}{|c|}{$\begin{array}{l}\text { Kesinlikle } \\
\text { Katılmıyo- } \\
\text { rum }\end{array}$} & \multicolumn{2}{|c|}{$\begin{array}{l}\text { Katılmiyo- } \\
\text { rum }\end{array}$} & \multicolumn{2}{|c|}{$\begin{array}{l}\text { Ne Katıl1- } \\
\text { yorum Ne } \\
\text { Katılmıyo- } \\
\text { rum } \\
\end{array}$} & \multicolumn{2}{|c|}{$\begin{array}{l}\text { Katılıyo- } \\
\text { rum }\end{array}$} & \multicolumn{2}{|c|}{$\begin{array}{l}\text { Kesin- } \\
\text { likle Ka- } \\
\text { t1liyo- } \\
\text { rum } \\
\end{array}$} & \multirow[t]{2}{*}{$\begin{array}{l}\text { Orta- } \\
\text { lama } \\
\text { (Mean) }\end{array}$} & \multirow[t]{2}{*}{$\begin{array}{l}\text { Stan- } \\
\text { dart } \\
\text { Sapma }\end{array}$} \\
\hline & $\mathrm{n}$ & $\%$ & $\mathrm{n}$ & $\%$ & $\mathrm{n}$ & $\%$ & $\mathrm{n}$ & $\%$ & $\mathrm{n}$ & $\%$ & & \\
\hline $\begin{array}{l}\text { 3.1. Dar gelirliler için sosyal } \\
\text { konutlar üretilmektedir. }\end{array}$ & 12 & 15,6 & 41 & 53,2 & 13 & 16,9 & 9 & 11,7 & 2 & 2,6 & 2,325 & 0,9657 \\
\hline $\begin{array}{l}\text { 3.2. İnsanlar yerlerinden edil- } \\
\text { meden dönüşüm yapılmakta- } \\
\text { dır. }\end{array}$ & 8 & 10,4 & 17 & 22,1 & 21 & 27,3 & 30 & 39 & 1 & 1,3 & 2,987 & 1,045 \\
\hline $\begin{array}{l}\text { 3.3. Komşuluk ve mahalle kül- } \\
\text { türünü geliştirici mekânsal çö- } \\
\text { zümler (oturma alanları, yürü- } \\
\text { yüş yolları, toplanma yerleri, } \\
\text { hobi bahçeleri, ortak mekânlar } \\
\text { vd.) üretilmektedir. }\end{array}$ & 8 & 10,4 & 28 & 36,4 & 25 & 32,5 & 15 & 19,5 & 1 & 1,3 & 2,649 & 0,9565 \\
\hline $\begin{array}{l}\text { 3.4. Dönüşüm alanındaki in- } \\
\text { sanların, kişisel gelişimlerine } \\
\text { katkı verecek eğitim imkânları } \\
\text { (halk eğitim, belediye kursları } \\
\text { vd.) sağlanmaktadır. }\end{array}$ & 8 & 10,4 & 36 & 46,8 & 19 & 24,7 & 14 & 18,2 & 0 & 0 & 2,506 & 0,9122 \\
\hline $\begin{array}{l}\text { 3.5. Dönüşüm alanındaki mev- } \\
\text { cut kültürel kimlikler korun- } \\
\text { maktadır. }\end{array}$ & 6 & 7,8 & 27 & 35,1 & 21 & 27,3 & 19 & 24,7 & 4 & 5,2 & 2,844 & 1,0521 \\
\hline $\begin{array}{l}\text { 3.6. Daha güvenli bir çevre } \\
\text { oluşturulmaktadır. }\end{array}$ & 6 & 7,8 & 6 & 7,8 & 22 & 28,6 & 34 & 44,2 & 9 & 11,7 & 3,442 & 1,0575 \\
\hline
\end{tabular}


Tablo 3. Sosyal boyuta yönelik önermeler. (Devam)

\begin{tabular}{lllllllllllll}
\hline $\begin{array}{l}\text { 3.7. Dönüşüm sonrasında böl- } \\
\text { gede kiralar makul seviyelerde } \\
\text { artmakta ve mevcut kiracılar } \\
\text { aynı bölgede yaşamlarına de- } \\
\text { vam etmektedirler. }\end{array}$ & 6 & 7,8 & 29 & 37,7 & 13 & 16,9 & 28 & 36,4 & 1 & 1,3 & 2,857 & 1,0477 \\
\hline $\begin{array}{l}\text { 3.8. Kamu kurumlarına ve } \\
\text { kamu görevlilerine erişebilirlik } \\
\text { daha kolay hale getirilmekte- } \\
\text { dir. }\end{array}$ & 9 & 11,7 & 28 & 36,4 & 19 & 24,7 & 19 & 24,7 & 2 & 2,6 & 2,701 & 1,0521 \\
\hline $\begin{array}{l}\text { 3.9. Her alandaki mevcut de- } \\
\text { mografik yapısya göre ayrı ayrı } \\
\text { dönüşüm çalışmaları gerçek- } \\
\text { leştirilmektedir. }\end{array}$ & 3 & 3,9 & 22 & 28,6 & 15 & 19,5 & 32 & 41,6 & 5 & 6,5 & 3,182 & 1,1557 \\
\hline
\end{tabular}

Mevcut kentsel dönüşüm uygulamalarında, belediyeler açısından dar gelirlilere yönelik sosyal konutlar imar edilmediği \%68,8 oranıyla dile getirilmektedir [Bkz. Önerme 3.1.]. Bunun yanında kentsel dönüşüm uygulamalarında insanların yerlerinden edilmedikleri \%40,3 oranıla belirtilmektedir. İnsanların yerlerinden edildiğini düşünenlerin oranı ise \%32,5’tir [Bkz. Önerme 3.2.]. Mahalle kültürünü ve komşuluk ilişkilerini geliştirici şekilde yapı üretildiğini dile getirenlerin oranı $\% 20,8$; olumsuz görüş belirtenlerin oranı ise \%46,8 ile çoğunluktadır [Bkz. Önerme 3.3.]. Dönüşüm uygulanan alanlarda insanların kişisel gelişimlerini sağlayacak çözümlerin üretilmediğini düşünenlerin oranı da çoğunluk çıkmıştır ve bu oran \%57,2'dir [Bkz. Önerme 3.4.]. Dönüşüm yapılan alanda mevcut kültürel kimliğin korunmadığını belirtenlerin oranı \%42,9'dur [Bkz. Önerme 3.5.].

Kentsel dönüşüm neticesinde üretilen alanların daha güvenli olduğunu belirtenlerin oranı \%55,9'dur [Bkz. Önerme 3.6.]. Yeni yapılaşma şekli güvenlikli siteler üzerinden oluşturulduğu için bu sonuç anlaşılabilir bir değerdir. Dönüşümle birlikte bölgedeki kiraların makul seviyeden daha fazla artı̆̆̆ını ve mevcut kiracıların başka yerlere taşındıklarını dile getirenlerin oranı \%45,5'tir (katılmayanların oranı \%37,7'dir) [Bkz. Önerme 3.7]. Kamu kurumlarına ve kamu görevlilerine ulaşılmasını kolaylaştıracak çözümlerin üretildiğini düşünenlerin oranı \%27,3 ile azınlıkta kalmış; buna katılmayanların oranı \%48,1 çıkmıştır [Bkz. Önerme 3.8.]. Bunların yanında, her dönüşüm bölgesindeki demografik yapılara göre ayrı ayrı çalışmalar yapıldı̆̆ını dile getirenlerin oranı da \%48,1'dir (olumsuz görüş belirtenlerin oranı \%32,5'tir) [Bkz. Önerme 3.9.]. 
Tablo 4. Planlama boyutuna yönelik önermeler.

\begin{tabular}{|c|c|c|c|c|c|c|c|c|c|c|c|c|}
\hline \multirow[t]{2}{*}{ Önermeler } & \multicolumn{2}{|c|}{$\begin{array}{l}\text { esinlikle Ka- } \\
\text { tılmıyorum }\end{array}$} & \multicolumn{2}{|c|}{$\begin{array}{l}\text { Katılmiyo- } \\
\text { rum }\end{array}$} & \multicolumn{2}{|c|}{$\begin{array}{l}\text { Ne Katılı- } \\
\text { yorum Ne } \\
\text { Katılmıyo- } \\
\text { rum }\end{array}$} & \multicolumn{2}{|c|}{$\begin{array}{l}\text { Katıliyo- } \\
\text { rum }\end{array}$} & \multicolumn{2}{|c|}{$\begin{array}{l}\text { Kesin- } \\
\text { likle Ka- } \\
\text { tıliyo- } \\
\text { rum }\end{array}$} & \multirow[t]{2}{*}{$\begin{array}{l}\text { Orta- } \\
\text { lama } \\
\text { (Mean) }\end{array}$} & \multirow[t]{2}{*}{$\begin{array}{l}\text { Stan- } \\
\text { dart } \\
\text { Sapma }\end{array}$} \\
\hline & $\mathrm{n}$ & $\%$ & $\mathrm{n}$ & $\%$ & $\mathrm{~N}$ & $\%$ & $\mathrm{n}$ & $\%$ & $\mathrm{n}$ & $\%$ & & \\
\hline $\begin{array}{l}\text { 4.1. Kentsel dönüşüm projeleri } \\
\text { mevcut planlar (çevre düzeni } \\
\text { planı, nazım imar planı vb.) ile } \\
\text { uyumludur. }\end{array}$ & 12 & 15,6 & 29 & 37,7 & 16 & 20,8 & 15 & 19,5 & 5 & 6,5 & 2,636 & 1,1575 \\
\hline $\begin{array}{l}\text { 4.2. Kentsel dönüşüm planları } \\
\text { güncel bilimsel yaklaşımlara ve } \\
\text { araştırmalara uygun olarak ha- } \\
\text { zırlanmaktadırlar. }\end{array}$ & 13 & 16,9 & 32 & 41,6 & 17 & 22,1 & 13 & 16,9 & 2 & 2,6 & 2,468 & 1,0461 \\
\hline $\begin{array}{l}\text { 4.3. Mekânsal Planlar Yapım } \\
\text { Yönetmeliği'nin ek-2 tablo- } \\
\text { sunda belirtilen asgari sosyal } \\
\text { ve teknik altyapı standartlarına } \\
\text { uyulmaktadır. }\end{array}$ & 11 & 14,3 & 31 & 40,3 & 21 & 27,3 & 14 & 18,2 & 0 & 0 & 2,494 & 0,9545 \\
\hline $\begin{array}{l}\text { 4.4. Kentsel dönüşümle birlikte } \\
\text { üretilen yeni doku, kentin mev- } \\
\text { cut mimari dokusuyla uyumlu- } \\
\text { dur. }\end{array}$ & 17 & 22,1 & 35 & 45,5 & 14 & 18,2 & 10 & 13 & 1 & 1,3 & 2,261 & 0,9921 \\
\hline $\begin{array}{l}\text { 4.5. Kentsel dönüşüme yönelik } \\
\text { planlamalar, özellikle kentsel } \\
\text { dönüşüm konusunda uzman- } \\
\text { laşmış kişilerce hazırlanmakta- } \\
\text { dır. }\end{array}$ & 5 & 6,5 & 44 & 57,1 & 17 & 22,1 & 8 & 10,4 & 3 & 3,9 & 2,481 & 0,9121 \\
\hline
\end{tabular}

Planlama konusuyla ilgili olarak, belediyeler açısından kentsel dönüşüm uygulamalarında mevcut çevre düzeni planına ve nazım imar planlarına olan uyum \%53,3 oranında olumsuz görülmektedir [Bkz. Önerme 4.1.]. Kentsel dönüşüme yönelik hazırlanan planların güncel bilimsel yaklaşımlara göre hazırlanmadığı \%58,5 oranıla belirtilmiştir [Bkz. Önerme 4.2.]. Mekânsal Planlar Yapım Yönetmeliğgi'ne uyulmadığı ise \%54,6 oranıla dile getirilmektedir [Bkz. Önerme 4.3.]. Kentsel dönüşümle üretilen yeni dokunun, kentin mevcut dokusuyla uyumsuz olduğunu söyleyenlerin oranı \%67,6'dır [Bkz. Önerme 4.4.]. Bunların yanında, kentsel dönüşüm planlarının, özellikle kentsel dönüşüm alanında uzmanlaşmış kişilerce hazırlanmadığı da \%63,6 oranıyla belirtilmektedir [Bkz. Önerme 4.5.]. 
Tablo 5. Ekonomik boyuta yönelik önermeler.

\begin{tabular}{|c|c|c|c|c|c|c|c|c|c|c|c|c|}
\hline \multirow[t]{2}{*}{ Önermeler } & \multicolumn{2}{|c|}{$\begin{array}{c}\text { Kesinlikle Ka } \\
\text { tılmıyorum }\end{array}$} & \multicolumn{2}{|c|}{$\begin{array}{l}\text { Katılmiyo- } \\
\text { rum }\end{array}$} & \multicolumn{2}{|c|}{$\begin{array}{l}\text { Ne Katıl1- } \\
\text { yorum } \mathrm{Ne} \\
\text { Katılmiyo- } \\
\text { rum }\end{array}$} & \multicolumn{2}{|c|}{$\begin{array}{l}\text { Katıliyo- } \\
\text { rum }\end{array}$} & \multicolumn{2}{|c|}{$\begin{array}{l}\text { Kesin- } \\
\text { likle } \\
\text { Katıl1- } \\
\text { yorum }\end{array}$} & \multirow[t]{2}{*}{$\begin{array}{l}\text { Orta- } \\
\text { lama } \\
\text { (Mean) }\end{array}$} & \multirow[t]{2}{*}{$\begin{array}{l}\text { Stan- } \\
\text { dart } \\
\text { Sapma }\end{array}$} \\
\hline & $\mathrm{n}$ & $\%$ & $\mathrm{n}$ & $\%$ & $\mathrm{~N}$ & $\%$ & $\mathrm{n}$ & $\%$ & $\mathrm{n}$ & $\%$ & & \\
\hline $\begin{array}{l}\text { 5.1. Dönüşüm sonrası meydana } \\
\text { gelen ekonomik faydadan, il- } \\
\text { gili toplumsal kesimler adaletli } \\
\text { bir şekilde yararlanmaktadır. }\end{array}$ & 12 & 15,6 & 24 & 31,2 & 26 & 33,8 & 13 & 16,9 & 2 & 2,6 & 2,597 & 1,0293 \\
\hline $\begin{array}{l}\text { 5.2. Kentsel dönüşüm yapılan } \\
\text { alanlar için ticarî mekânlar da } \\
\text { yeterli düzeyde üretilmektedir. }\end{array}$ & 3 & 3,9 & 37 & 48,1 & 22 & 28,6 & 12 & 15,6 & 3 & 3,9 & 2,675 & 0,924 \\
\hline $\begin{array}{l}\text { 5.3. Afetlere dayanıklı mekan- } \\
\text { ların üretilmesi, rant elde etme } \\
\text { amacının önünde yer almakta- } \\
\text { dır. }\end{array}$ & 5 & 6,5 & 21 & 27,3 & 12 & 15,6 & 34 & 44,2 & 5 & 6,5 & 3,169 & 1,105 \\
\hline $\begin{array}{l}\text { 5.4. Dönüşüm yapılan alan- } \\
\text { larda dar gelirliler de konut sa- } \\
\text { hibi olabilmektedirler. }\end{array}$ & 16 & 20,8 & 25 & 32,5 & 18 & 23,4 & 16 & 20,8 & 2 & 2,6 & 2,519 & 1,1193 \\
\hline $\begin{array}{l}\text { 5.5. Dönüşüm yapılan yerlerde } \\
\text { geleneksel meslekler yaşatıl- } \\
\text { maktadır. }\end{array}$ & 15 & 19,5 & 34 & 44,2 & 15 & 19,5 & 13 & 16,9 & 0 & 0 & 2,338 & 0,9815 \\
\hline $\begin{array}{l}\text { 5.6. Yerel ve bölgesel kalkın- } \\
\text { maya katkı sunacak şekilde, } \\
\text { dönüşüm alanında ticari üret- } \\
\text { kenlik meydana getirilmekte- } \\
\text { dir. }\end{array}$ & 9 & 11,7 & 36 & 46,8 & 17 & 22,1 & 14 & 18,2 & 1 & 1,3 & 2,506 & 0,9682 \\
\hline
\end{tabular}

Belediyelere göre mevcut kentsel dönüşüm uygulamalarında, meydana gelen ekonomik değerden (buna rant geliri de eklenebilir) bölgedeki toplumsal kesimlerin etkin bir şekilde yararlandığ $\% 19,5$ oranıyla dile getirilirken; olumsuz görüş belirtenlerin oranı $\% 46,8$ 'dir [Bkz. Önerme 5.1.]. Dönüşüm alanlarında ticari mekânların yeterli seviyede üretilmediği ise \%52 ile belirtilmektedir [Bkz. Önerme 5.2.]. Depreme dayanıklı yapı stokunun arttırılması hedefinin, rant elde etmekten önce geldiğini söyleyenlerin oranı \%50,7'dir [Bkz. Önerme 5.3.]. Fakat kentsel dönüşüm alanlarında dar gelirlilerin konut sahibi olmadığını düşünenlerin oranı çoğunlukta çıkmış ve bu oran \%53,3 olmuştur [Bkz. Önerme 5.4.]. Dönüşüm yapılan alanlarda geleneksel mesleklerin yaşatılmadığ $1 \% 63,7$ oranıla dile getirilmektedir [Bkz. Önerme 5.5.]. Son olarak, kentsel dönüşümle birlikte yerel ve bölgesel kalkınmaya katkı sağlayacak şekilde, dönüşüm alanlarında ticari üretkenlik yaratılamadığını düşünenlerin oranı $\% 58,5$ olmuştur [Bkz. Önerme5.6.]. 
Tablo 6. Yönetişim boyutuna yönelik önermeler.

\begin{tabular}{|c|c|c|c|c|c|c|c|c|c|c|c|c|}
\hline \multirow[t]{2}{*}{ Önermeler } & \multicolumn{2}{|c|}{$\begin{array}{c}\text { Kesinlikle } \\
\text { Katılmıyo- } \\
\text { rum }\end{array}$} & \multicolumn{2}{|c|}{$\begin{array}{c}\text { Katılm1- } \\
\text { yorum }\end{array}$} & \multicolumn{2}{|c|}{$\begin{array}{l}\text { Ne Katıl1- } \\
\text { yorum Ne } \\
\text { Katılm1- } \\
\text { yorum } \\
\end{array}$} & \multicolumn{2}{|c|}{$\begin{array}{l}\text { Katıl1- } \\
\text { yorum }\end{array}$} & \multicolumn{2}{|c|}{$\begin{array}{l}\text { Kesin- } \\
\text { likle } \\
\text { Katıl1- } \\
\text { yorum } \\
\end{array}$} & \multirow[t]{2}{*}{$\begin{array}{l}\text { Orta- } \\
\text { lama } \\
\text { (Mean) }\end{array}$} & \multirow[t]{2}{*}{$\begin{array}{l}\text { Stan- } \\
\text { dart } \\
\text { Sapma }\end{array}$} \\
\hline & $\mathrm{n}$ & $\%$ & $\mathrm{n}$ & $\%$ & $\mathrm{~N}$ & $\%$ & $\mathrm{n}$ & $\%$ & $\mathrm{n}$ & $\%$ & & \\
\hline $\begin{array}{l}\text { 6.1. Uygulama alanının ve } \\
\text { yapılaşma şeklinin belirlen- } \\
\text { mesinde halkın katılımı ye- } \\
\text { terli düzeyde sağlanmakta- } \\
\text { dır. }\end{array}$ & 13 & 16,9 & 24 & 31,2 & 19 & 24,7 & 20 & 26 & 1 & 1,3 & 2,636 & 1,0871 \\
\hline $\begin{array}{l}\text { 6.2. Uygulama alanının ve } \\
\text { yapılaşma şeklinin belirlen- } \\
\text { mesinde sivil toplum kuru- } \\
\text { luşlarının (dernek, vakıf, } \\
\text { sendika, hemşeri derneği } \\
\text { vd.) katılımı yeterli düzeyde } \\
\text { sağlanmaktadır. }\end{array}$ & 12 & 15,6 & 35 & 45,5 & 16 & 20,8 & 14 & 18,2 & 0 & 0 & 2,416 & 0,9645 \\
\hline $\begin{array}{l}\text { 6.3. Uygulama alanının ve } \\
\text { yapılaşma şeklinin belirlen- } \\
\text { mesinde meslek odalarının } \\
\text { (Mimarlar Odası, Peyzaj Mi- } \\
\text { marları Odası, İnşaat Mü- } \\
\text { hendisleri Odası vd.) katı- } \\
\text { lımı yeterli düzeyde sağlan- } \\
\text { maktadır. }\end{array}$ & 18 & 23,4 & 28 & 36,4 & 18 & 23,4 & 13 & 16,9 & 0 & 0 & 2,338 & 1,021 \\
\hline $\begin{array}{l}\text { 6.4. Uygulama alanının ve } \\
\text { yapılaşma şeklinin belirlen- } \\
\text { mesinde, özel sektörün (mü- } \\
\text { teahhitlik firmaları, banka- } \\
\text { lar, finans kuruluşları) belir- } \\
\text { leyici olmasına izin veril- } \\
\text { mektedir. }\end{array}$ & 20 & 26 & 28 & 36,4 & 16 & 20,8 & 12 & 15,6 & 1 & 1,3 & 2,299 & 1,0646 \\
\hline
\end{tabular}

Belediyeler açısından yönetişim boyutunda; kentsel dönüşüm uygulamalarının alanı ve yapılaşma şekli belirlenirken, halkın katılımının yetersiz olduğu \%48,1 ile dile getirilmektedir. Halkın katılımının yeterli seviyede olduğunu düşünenlerin oranı \%27,3 ile azınlıktadır [Bkz. Önerme 6.1.]. Kentsel dönüşüm sırasında uygulama alanının ve yapılaşma şeklinin belirlenmesine diğer paydaşların katılımı sorulduğunda da yanıtlar çoğunlukla olumsuz yönde gelmiştir. Bu kapsamda sivil toplum kuruluşlarının (sendika, dernek, vakıf, vd.) \%61,1 [Bkz. Önerme 6.2.] ve meslek odalar1nın (Mimarlar Odası, İnşaat Mühendisleri Odası, Peyzaj Mimarları Odası, vd.) \%59,8 oranıla katılımcllık gösteremedikleri belirtilmiştir [Bkz. Önerme 6.3.]. Bunlara ilave olarak, özel sektörün (müteahhitlik firmaları, 
finans kuruluşları, bankalar, vd.) kentsel dönüşümde belirleyici olmadığ1 da \%62,4 oraniyla dile getirilmiştir [Bkz. Önerme 6.4].

Tablo 7. Hukuki boyuta yönelik önermeler.

\begin{tabular}{|c|c|c|c|c|c|c|c|c|c|c|c|c|}
\hline \multirow[t]{2}{*}{ Önermeler } & \multicolumn{2}{|c|}{$\begin{array}{l}\text { Kesinlikle } \\
\text { Katılm1- } \\
\text { yorum }\end{array}$} & \multicolumn{2}{|c|}{$\begin{array}{c}\text { Katılm1- } \\
\text { yorum }\end{array}$} & \multicolumn{2}{|c|}{$\begin{array}{l}\text { Ne Katıl1- } \\
\text { yorum Ne } \\
\text { Katılmı- } \\
\text { yorum }\end{array}$} & \multicolumn{2}{|c|}{$\begin{array}{l}\text { Katıl1- } \\
\text { yorum }\end{array}$} & \multicolumn{2}{|c|}{$\begin{array}{l}\text { Kesin- } \\
\text { likle Ka- } \\
\text { tılıyo- } \\
\text { rum }\end{array}$} & \multirow[t]{2}{*}{$\begin{array}{l}\text { Orta- } \\
\text { lama } \\
\text { (Mean) }\end{array}$} & \multirow[t]{2}{*}{$\begin{array}{l}\text { Stan- } \\
\text { dart } \\
\text { Sapma }\end{array}$} \\
\hline & $\mathrm{n}$ & $\%$ & $\mathrm{n}$ & $\%$ & $\mathrm{n}$ & $\%$ & $\mathrm{n}$ & $\%$ & $\mathrm{n}$ & $\%$ & & \\
\hline $\begin{array}{l}\text { 7.1. Mülkiyet hakları (kişinin } \\
\text { mülkünü dilediği gibi de- } \\
\text { ğerlendirme, dilediği za- } \\
\text { manda kentsel dönüşüme } \\
\text { dâhil olma vd.) dönüşüm ça- } \\
\text { lışmalarında dikkate alın- } \\
\text { maktadır. }\end{array}$ & 10 & 13 & 25 & 32,5 & 16 & 20,8 & 24 & 31,2 & 2 & 2,6 & 2,779 & 1,1077 \\
\hline $\begin{array}{l}\text { 7.2. Dönüşümle ilgili açılan } \\
\text { davalar uygun zaman dili- } \\
\text { minde sonuçlanmaktadır. }\end{array}$ & 9 & 11,7 & 21 & 27,3 & 32 & 41,6 & 13 & 16,9 & 2 & 2,6 & 2,714 & 0,9714 \\
\hline $\begin{array}{l}\text { 7.3. İnsanlara kentsel dönü- } \\
\text { şümle ilgili hukuki haklarını } \\
\text { rahat ve doğru bir şekilde } \\
\text { öğrenebilecekleri imkânlar } \\
\text { sunulmaktadır. }\end{array}$ & 8 & 10,4 & 35 & 45,5 & 18 & 23,4 & 13 & 16,9 & 3 & 3,9 & 2,584 & 1,0176 \\
\hline $\begin{array}{l}\text { 7.4. Kentsel dönüşüm çalış- } \\
\text { maları mevzuata uygun ola- } \\
\text { rak yürütülmektedir. }\end{array}$ & 5 & 6,5 & 9 & 11,7 & 7 & 9,1 & 43 & 55,8 & 13 & 16,9 & 3,649 & 1,0979 \\
\hline $\begin{array}{l}\text { 7.5. Kazanılmış haklar (veril- } \\
\text { miş yapı ruhsatları, sahip } \\
\text { olunan mekân ölçütleri, tapu } \\
\text { belgeleri) dönüşüm çalışma- } \\
\text { ları sırasında korunmakta- } \\
\text { dır. }\end{array}$ & 1 & 1,3 & 8 & 10,4 & 15 & 19,5 & 42 & 54,5 & 11 & 14,3 & 3,701 & 0,8895 \\
\hline
\end{tabular}

Belediyeler açısından hukuki boyuta bakıldığında; mevcut kentsel dönüşüm uygulamalarında mülkiyet haklarının (mülk sahiplerinin istediği zamanda kentsel dönüşüme dâhil olması, mülkünü dilediği gibi değerlendirmesi, vd.) dikkate alındığı \%33,8 gibi düşük bir oranda dile getirilmiş; $\% 45,5$ oranında ise olumsuz görüş belirtilmiştir [Bkz. Önerme 7.1.]. Kentsel dönüşümle ilgili açılan davaların kısa bir zaman diliminde çözüme kavuşturulduğunu düşünenlerin oranı \%19,5'dir [Bkz. Önerme 7.2.]. Bölgede yaşayan insanlara kentsel dönüşümle ilgili hukuki haklarını rahatça öğrenebilecekleri imkânların sunulmadığını belirtenlerin oranı \%55,9'dur [Bkz. Önerme 7.3.]. Bunlara ilave olarak, yapılan kentsel dönüşüm uygu- 
lamalarının hukuki mevzuata uygun şekilde gerçekleştirildiğini dile getirenlerin oranı \%72,7 gibi yüksek bir değerde çkmıştır [Bkz. Önerme 7.4.]. Ayrıca kentsel dönüşüm sırasında kazanılmış hakların (sahip olunan mekân ölçüleri, tapu belgeleri, verilmiş yapı ruhsatları) korunduğunu belirten oranı da yüksek çıkarak \%68,8 olmuştur [Bkz. Önerme 7.5.].

\section{Sonuç}

Kentsel dönüşüm kavramının Sanayi Devrimiyle birlikte ortaya çıtığ1 göz önüne alınırsa, binlerce yıllık geçmişi bulunan insanlık için oldukça yeni bir zaman diliminin eseri olduğu söylenebilir. Bu bakımdan kentsel dönüşüme yönelik yeni bakış açıları, düzenlemeler ve onu daha iyi bir hale getirmeye yönelik arayışlar tüm dünya genelinde ortaya konulmaktadır. Bunun yanında bir ülkenin sahip olduğu kültürel, ekonomik ve sosyal yapısı; ne şekilde bir kentsel dönüşüm anlayışına sahip olduğunu göstermektedir. Konuyla ilgili olarak, Türkiye ölçeğinde özellikle 1999 Gölcük ve Düzce depremleri ile ülkenin ana gündem maddelerinden birisi haline gelen kentsel dönüşüm kavramı, son 20 yılın en önemli ulusal uygulamalarından birisi olmuştur. Dolayısıyla Türkiye ölçeğinde ortaya konulan kentsel dönüşümün henüz yeni tecrübe edilen bir çalışma alanı olduğunu söylemek yanlış olmayacaktır.

Türkiye'nin ve diğer kentsel dönüşüm uygulayan ülkelerin kentleşme ve kentsel dönüşüm geçmişleri farklılıklar göstermektedir. Bu bakımdan Türkiye ile diğer ülkeleri kentsel dönüşüm alanında kıyaslamak kolay bir karşılaştırma olmamaktadır. Gelişmiş ülkeler 1750'lerden itibaren Sanayi Devrimiyle birlikte kentsel sorunlarla karşılaşıp bunlara yönelik kentsel dönüşüm uygulamaları ortaya koyarken; Türkiye 1950'lerden itibaren kentsel sorunlarla karşılaşmaya başlamış, 2000'lerden sonra da kentsel dönüşümü üst seviyelerde uygulama başlamıştır. Bu sebeple Türkiye'yi öncelikli olarak kendi konumunda değerlendirmek ve mevcut durumu tespit etmek doğru olacaktır. Bu kapsamda, Türkiye'deki en önemli kentsel dönüşüm uygulayıcısı olan belediyelerin, bu alandaki görüşlerini öğrenmek konuyla ilgili çalışmalara katkı sağlayabilir. Dolayısıyla bu çalışma kapsamında, Türkiye'deki belediyelerin kentsel dönüşüm alanındaki görüşlerini öğrenmek için bir saha araştırması yapılmıştır. Sonuçlarda görülmektedir ki; Türkiye'de uygulanan kentsel dönüşüm çalışmalarında önemli sorunlar mevcuttur. Bu kapsamda anketle birlikte hem aktörlere 
hem de uygulamaların boyutlarına yönelik ortaya konulan olumlu yöndeki önermelere, büyük oranda olumsuz görüşler beyan edilmiştir.

İstanbul şehrindeki belediyelerde gerçekleştirilen saha araştırmasında çıkan bu sonuç, kentsel dönüşüm alanında iyileştirmelere ihtiyaç duyulduğunu göstermektedir. Bu kapsamda, Türkiye ölçeğinde aktörlerin ve uygulamaların yeniden gözden geçirilmesi faydalı olabilir. Kentsel dönüşümün fiziksel, sosyal, ekonomik, planlama, yönetişim ve hukuki boyutlarında daha etkin ve verimli çalışmalara ihtiyaç duyulduğu görülmektedir. Çalışmayla ilgili olarak sonuçları daha bütüncül bir şekilde yorumlamak da mümkündür;

- Aktörlere ilişkin sonuçlar: Belediyelerin görüşüne göre, ÇŞB ve TOKİ'nin kentsel dönüşüm kapsamında kendi başlarına karar almaları kentin mevcut mimari bütünlügünü bozabilmektedir [Önerme 1.1., 1.3., 1.4., 1.5. ve 1.6.]. Bunun sonucunda da kentin tarihsel süreçte ortaya çıkmış olan kimliği ve estetik değerleri zarar görebilmektedir. Ayrıca belediyelerin kentsel dönüşüm alanında diğer aktörlerin faaliyet göstermelerinden rahatsız oldukları görülmektedir [Önerme 1.7.]. Daha net bir ifadeyle, kentsel dönüşüm konusunda belediyeler tek yetkili aktör olmayı istemektedirler. Kenti imar etmek ve geliştirmek üzere görevlendirilmiş olan; bunun yanında kentin en önemli idare edicisi konumunda bulunan bir kurumun bu yönde bir görüş belirtmesi anlaşılabilir bir sonuçtur.

- Fiziksel boyuta ilişkin sonuçlar: Belediyelerin belirttiklerine göre, mevcut kentsel dönüşüm uygulamalarında fiziksel boyuta ilişkin önemli sorunlar mevcuttur. Kentsel dönüşüm en temelinde fiziksel sorunların bertaraf edilmesi amacıyla ortaya konulmasına rağmen, bu alanda etkin sonuçların alınamaması önemli bir sorun olarak karşımıza çıkmaktadır. Alt ve üst yapının yeterli seviyede geliştirilememesi [Önerme 2.1., 2.2.], yeterli seviyede yeşil alan üretilememesi [Önerme 2.3.], tarihi kent kimliğinin korunamaması [Önerme 2.4.], engellilere yönelik çözüm önerilerinin geliştirilememesi [Önerme 2.6.], kültür ve sanat mekanlarının üretilememesi [Önerme 2.7.], yenilenebilir enerji ve atık dönüşüm sistemlerinin yaygınlaştırılamaması [Önerme 2.10 ve 2.11.], yapı ve nüfus yoğunluğunun kontrol altına alınamaması [Önerme 2.13.], doğal ve ekolojik çevreyle uyumun sağlanamaması [Önerme 2.14.], 
kentsel kimliğin ve estetik değerlerin korunamaması [Önerme 2.15.] bu alanda öne çıkan sorunlardır.

- Sosyal boyuta ilişkin sonuçlar: Kentsel dönüşüm uygulamalarında insan unsuru en merkezde yer almaktadır. Bunun sebebi kentin içinde yaşayan insanlar için dönüştürülmesidir. Fakat belediyelerin görüşüne göre, sosyal boyutta yeterli seviyede etkin çalışmalar ortaya konulamamaktadır. Bu bakımdan insanların sosyal yönden gelişimine katkı sunan mekânların geliştirilmesine ihtiyaç olduğu görülmektedir. Dar gelirlilere yönelik çözüm önerilerinin geliştirilememesi [Önerme 3.1.], mahalle kültürünün korunamaması [Önerme 3.3.], dönüşüm alanındaki kültürel kimliklere önem verilmemesi [Önerme 3.5.] ve kiracıların dikkate alınmaması [Önerme 3.7.] bu alanda öne çıkan başlıca sorunlardır.

- Planlama boyutuna ilişkin sonuçlar: Belediyelerin dile getirdiğine göre mevcut kentsel dönüşüm planları, kentin mevcut çevre düzeni ve nazım imar planlarından bağımsız olarak oluşturulmaktadır. Bu durum da kentsel bütünlügü bozmaktadır. Bunun yanında kentsel dönüşüm planlarının kendi başlarına birer kentleşme planı gibi işlev görmeleri de bir sorun olarak görülmektedir. Bu anlayış neticesinde kentsel bütünlük, kentsel kimlik ve kentsel estetik zarar görebilmektedir. Mevcut çevre düzeni ve nazım imar planları ile kentsel dönüşüm planlarının uyumsuz oluşu [Önerme 4.1.], kamunun kendi bünyesinde belirlediği kanun ve yönetmeliklere bizzat kamunun kendisi tarafından uyulmaması [Önerme 4.3.], kentsel dönüşümle üretilen yeni dokunun mevcut kentsel dokuyla uyumsuz oluşu [Önerme 4.4.] ve kentsel dönüşüm planlamalarının konunun uzmanı olan kişilerce hazırlanmaması [Önerme 4.5.] bu alanda öne çıan başlıca sorunlardır.

- Ekonomik boyuta ilişkin sonuçlar: Gelişmiş ülkelerdeki kentsel dönüşüm uygulamalarında, ekonominin geliştirilmesine yönelik çözüm önerileri üretilmektedir. Fakat belediyeler açısından Türkiye ölçeğinde durum bundan farklıdır. Dönüşüm uygulanan alanlarda, yeteri kadar ticari üretkenlik ortaya koyan mekân üretilmediği dile getirilmektedir. Bunun neticesinde kentsel dönüşüm uygulamaları sırasında yerel (mikro) ve ulusal (makro) ekonominin geliştirilmesine yönelik bir kazanım elde edilemediği görülmektedir. Kentsel dönüşüm uygulamaları ile daha çok konut ağırlıklı bir yapılaşma hayata geçirilmekte [Önerme 5.2.]; yerel 
(mikro) ve ulusal (makro) ölçekte ekonomik üretkenlik ortaya koyacak çözümler ihtiyaç duyulan seviyede geliştirilmemektedir [Önerme 5.6.]. Ayrıca kentsel dönüşüm uygulanan alanlarda dar gelirliler için konut üretilmemesi [Önerme 5.4.] ve geleneksel mesleklerin yaşatılmaması da [Önerme 5.5.] bu alanda öne çıan diğer başlıca sorunlardır.

- Yönetişim boyutuna ilişkin sonuçlar: Kentsel dönüşüm uygulaması kenti dönüştürdüğü için, kentsel mutabakat ile gerçekleştirilmesi gereken bir faaliyettir. Fakat belediyelerin dile getirdiklerine göre, Türkiye ölçeğinde paydaşların kentsel dönüşüm süreçlerine katılımlarına yeterli seviyede imkân tanınmamaktadır [Önerme 6.1., 6.2. ve 6.3.]. Bunun neticesinde konunun tarafları ve uzmanları dışarda bırakılmakta; dolayısıyla kentsel dönüşüm uygulamalarının nitelikleri yetersiz kalabilmektedir.

- Hukuki boyuta ilişkin sonuçlar: Kentsel dönüşüm çalışmaları en temelinde hukuki zeminde hayata geçirilmektedirler. Belediyelerin bu konudaki görüşlerine bakıldığında, dönüşüm alanındaki insanların mülkiyet haklarının güvence atına alındığı ve yapılan çalışmalarda hukuki mevzuata uyulduğu söylenmektedir [Önerme 7.4. ve 7.5.]. Fakat dönüşüm bölgelerinde insanlara hukuki hakları konusunda yeterli seviyede bilgilendirme yapılmadığı belirtilmektedir [Önerme 7.3.]. Ayrıca kentsel dönüşüm kapsamında açılan davaların kısa bir zaman diliminde sonuca bağlanamadığ 1 da dile getirilmektedir [Önerme 7.2.]. 


\section{Extended Abstract}

\section{Attitudes of The Municipalities to the Existing Urban Transformation Works in Turkey: A Research Through Istanbul County Municipalities}

Onur Kemal Yilmaz

Marmara University
Recep Bozdoğan

Marmara University

How effective works are on the physical, economic, social, governance, legal and planning dimensions of urban transformation in Turkey? In this context, this study aims to determine the quality of urban transformation works from the point of municipalities. This is because municipalities are the most important urban transformation practitioners. A questionnaire was prepared for the study and this survey was applied to the district municipalities of Istanbul. The survey included 77 principals from 39 district municipalities. It has been determined that, there are problems on the physical, economic, social, planning, governance and legal dimensions of urban transformation in terms of municipalities. The results of the research on actors and dimensions are as follows:

Table 1. About the actors: $70.2 \%$ negative ratio is on the TOKI's (Housing Authority) giving urban transformation decision by itself. This ratio is $58.5 \%$ for the Ministry of Environment and Urbanization (MoEU) and property owners. Municipalities state with $58.5 \%$ rate that the transformation works implemented by the MoEU and TOKI changed the existing zoning plan of the city. The $65 \%$ of participants state that, the buildings produced by TOKI disrupt the existing aesthetics and identity of the city. Finally, within the scope of the actors, $40.2 \%$ of the respondents stated that the powers of urban transformation of the MoEU and TOKI must be transferred to the municipalities.

Table 2: About the physical dimension: $49.4 \%$ of participants think that the infrastructure system has been developed to meet the needs of the region during the urban transformation. However, the rate of those who think 
that the transportation infrastructure is not developed sufficiently during the urban transformation works is $42.2 \%$. The ratio of those who think that there is not enough green space being produced during the urban transformation works is high with $63.7 \%$. The rate of those who think that the historical identity of the city is not protected during the transformation works is $57.2 \%$. According to the municipalities, the city is adapted to the disabled by $23.4 \%$ in the current urban transformation works. $55.9 \%$ of the participants stated that culture and art spaces are not produced enough with urban transformation. The rate of those who stated that health institutions are not being produced enough is \%50.7; the rate of those who stated that spaces for the elderly are not being produced enough is $58.5 \%$; the rate of those who stated that sports and playgrounds for young people are not being produced enough is $44.2 \%$. In terms of municipalities, the rate of those who think that renewable energy sources are not generalised is $53.3 \%$. The rate of those who think that the facilities that will enable the recycling of waste is not developed is $61.1 \% .67 .6 \%$ of the respondents stated that the population and housing density were not kept at reasonable levels during the urban transformation works. The rate of those who stated that natural and ecological environment are not developed during applications is $67.6 \%$. The percentage of those who stated that the incompatible structures with the existing aesthetic values are being produced is $75.3 \%$. In addition, the rate of those who stated that noise, air and water pollution could not be controlled in the urban transformation areas is $66.3 \%$.

Table 3: About the social dimension: In terms of municipalities the rate is $68.8 \%$ that social dwellings for low-income people are not produced. In addition, $40.3 \%$ of participants mentioned that, during urban transformation works people are not displaced. $20.8 \%$ of the respondents state that the structures have been produced in a way that promotes neighborhood culture and neighborly relations. $42.9 \%$ of the respondents stated that the existing cultural identity is preserved in the area of transformation. The rate of those who stated that the areas produced as a result of urban transformation are safer is $55,9 \% .45 .5 \%$ of the respondents say that the rents in the region have increased more than the reasonable level and that the existing tenants have moved to other places during the transformation. In addition to these, the rate of those who stated that the works carried out separately according to the demographic structures in each transformation region is $48.1 \%$. 
Table 4: About the planning dimension: In terms of municipalities, the adaptation to the existing environmental plans and the master plans of zoning during urban transformation works is seen as negative by $53.3 \%$. It was stated that the plans were not prepared according to the current scientific approaches during urban transformation with a rate of $58.5 \%$. The noncompliance with the Regulation on Construction of Spatial Plans is expressed as $54.6 \%$. The rate of those who say that the new texture produced with urban transformation is incompatible with the existing texture of the city is $67.6 \%$. In addition to these, it is also stated that the urban transformation plans are not prepared by the experts in the field of urban transformation. The rate is $\% 63,6$ here.

Table 5: About the economic dimension: It is stated with $52 \%$ rate that, the commercial areas are not produced in the transformation areas. 50,7\% of the participants state that the aim of increasing the earthquake-resistant building stock comes before the rent. The percentage of those who think that the poorest in urban transformation areas do not have a homeowner is the majority and this rate is $53.3 \%$. It is stated with $63,7 \%$ rate that, the traditional occupations are not maintained in the areas where transformation is made. Lastly, the rate of those who think that commercial productivity are not created in the transformation areas is $58.5 \%$.

Table 6: About the governance dimension: It is stated by municipalities with $48.1 \%$ rate that, public participation is insufficient when determining the urban transformation works. In relation to other actors, it is stated with $\% 60$ rate that participation of non-governmental organizations and professional chambers is insufficient when determining the urban transformation works. In addition, $\% 62,4$ of participants mentioned that the private sector is not a determinant of urban transformation.

Table 7: About the legal dimension: It is stated with $33.8 \%$ rate that, property rights in existing urban renewal works being taking into account. The rate of those who think that the lawsuits during urban transformation are solved in a short period of time is $19.5 \% .55 .9 \%$ of participants stated that people in the region are not have the opportunity to learn legal rights about the urban transformation.

\section{Kaynakça/References}

Afacan, Y. (2015). Resident satisfaction for sustainable urban regeneration, ICE-Institution of Civil Engineers, 0(0), 1-16. 
Akkar, M. (2006). Kentsel dönüşüm üzerine Batı'daki kavramlar, tanımlar, süreçler ve Türkiye. Planlama Dergisi, (2), 29-38.

Alpaslan, H. İ. ve Tüter, A. (2016). Kentsel dönüşüm sürecinde TOKİ uygulamaları ve halkın algılarına göre değerlendirilmesi, İstanbul Sosyal Bilimler Dergisi, (12), 11-44.

Aykal, D., Murat, Ö., Korkmaz, M. ve Acar, B. (2007). Kentsel dönüşüm yaklaşımında kullanıcı memnuniyet analizi, D.Ü. Ziya Gökalp Eğitim Fakültesi Dergisi, (8), 95-111.

Bozdağ, A., İnam, Ş. ve Durduran, Ş. (2011). Kentsel dönüşüm uygulamalarına çok amaçlı yaklaşım, Bursa (İnegöl) kent örneği, Selçuk Üniversitesi Mühendislik Mimarlık Fakültesi Dergisi, 26(4), 124-139.

Bozlağan, R. (2005). Liderlik yaklaşımları ve belediyeler. İstanbul: Hayat Yayınları.

Colantino, A. ve Dixon, T. Measuring social sustainable urban regeneration in Europa, Erişim Adresi: http://oisd.brookes.ac.uk/sustainable_communities/resources/Social_Sustainability_and_Urban_Regeneration_report.pdf, Erişim Tarihi: 04.05.2018.

Couch, C. (1990). Urban renewal: Theory and practice. Londra: Macmillan Yayınları.

Duman, B. (2015). Kentsel dönüşümde riskler ve beklentilere dair ilk tespitler: İstanbul' da bir saha araştırması, Megaron, 10(3), 410-422.

Hamurcu, A. U. ve Buldurur, M. A. (2017). Sürdürülebilir kentsel dönüşüm için performans göstergeleri, Planlama, 27(3), 222-235.

Kahraman, Z. E. ve Özdemir, S. S. (2017). Kentsel dönüşümü gündeme gelen bir alan için konut memnuniyeti araştırması: Türk-İ̧s Blokları örneği, Megaron, 12(4), 619-634.

Karasar, N. (2012). Bilimsel araştırma yöntemi. Ankara: Nobel Yayınevi.

Kaya, M. F. (2013). Sürdürülebilir kalkınmaya yönelik tutum ölçeği geliştirme çalışması, Marmara Coğrafya Dergisi, (28), 175-193.

Kentsel dönüşüm anket çalışması. TMMOB İzmir İl Koordinasyon Kurulu, Erişim Adresi: http://www.tmmobizmir.org/wp-content/uploads/2014/06/84.pdf, Erişim Tarihi: 04.05.2018.

Keskin, R. ve Demirer, Ö. (2012). Şehirlerin fiziki modernizasyonu: Çorum uygulaması, Manas Sosyal Araştırmalar Dergisi, 1(4), 19-36.

Lee, $\mathrm{G}$ ve Chan, E. (2006). Effective approach to achieve sustainable urban renewal in densely populated cities, Erişim Adresi: https://www.irbnet.de/daten/iconda/06059012868.pdf, Erişim Tarihi: 04.05.2018.

Loures, L., Santos, R. ve Panagopoulus, T. (2007). Urban parks and sustainable city planning - The case of portimao. WSEAS Transactions on Environment and Development, 10(3), 171-180.

Mutlu, E. (2009). Criteria for a "good" urban renewal project: the case of Kadifekale urban renewal project, İzmir Yüksek Teknoloji Enstitüsü, Yüksek Lisans Tezi.

Oruç, G. D. ve Giritlioğlu, C. (2008). The evaluation of urban quality and vitality of the Istanbul historical peninsula - Eminönü District, İstanbul Teknik Üniversitesi Dergisi, 5(1), 97-117.

Öcal, T. ve Çelik, V. (2017). Yavuzlar (Yüreğir-Adana) Mahallesi kentsel dönüşümü İle TOKİ konutlarının karşılaştırmalı analizi, Marmara Coğrafya Dergisi, (36), 147-161.

Roberts, P. ve Sykes, H. (2008). Urban regeneration: A handbook. Londra: Sage Yayınevi.

The housing act 1937. Erişim Adresi: https://babel.hathitrust.org/cgi/pt?id=uc1.b3866883;view=1up;seq=1, Erişim Tarihi: 03.05.2018. 
The housing of the working classes act 1890. Erişim Adresi: https://archive.org/details/b2440147x, Erişim Tarihi: 03.05.2018.

Yaman, A., Arslan, C. ve Önalp, G. (2015). Türkiye'de kentleşme projelerinde yerel yönetimlerin rolü ve bu projelerin kentlileşmeye etkisi: Kars örneği, Ardahan Üniversitesi İktisadi ve İdari Bilimler Fakültesi Dergisi, (2), 53-69.

Onur Kemal Yılmaz, Anadolu Üniversitesi, İşletme Bölümü'nden lisans derecesi ile 2012 yılında mezun oldu. Tezli yüksek lisansını 2015 yılında İstanbul Üniversitesi, İstanbul Araştırmaları Bilim Dalı'nda tamamladı. Doktora eğitimini 2018 yılında Marmara Üniversitesi, Yerel Yönetimler bölümünde tamamlamıştır. Yazar, eğitim hayatı boyunca çeşitli özel sektör kuruluşlarında çalışmıştır. Akademik ilgi alanları belediyelerin ve kentlerin yönetilmesi üzerinedir.

Onur Kemal Yilmaz, He is graduated from Anadolu University, Department of Business with license degree in 2012. In 2015, he received his masters degree from Istanbul University in Istanbul Researches Department. He completed his Ph.D. in Marmara University in the field of Local Governments in 2018. He worked at various private sector organizations throughout his education life. His academic interests include municipalities and urban policies.

Recep Bozdoğan, 1995 yılında Orta Doğu Teknik Üniversitesi Siyaset Bilimi ve Kamu Yönetimi Bölümü'nden mezun oldu. Marmara Üniversitesi Kamu Yönetimi Bilim Dalı'nda yüksek lisans ve doktora yaptı. 2002 yılında yardımcı doçent, 2006 yılında doçent ve 2011 yılında profesör oldu. 2005-2006 yılları arasında İstanbul Büyükşehir Belediyesi'nde danışmanlık, 2006-2007 yılları arasında İstanbul İl Özel İdaresi'nde genel sekreter yardımcılığı ve 2007-2012 yılları arasında Marmara Belediyeler Birliği'nde genel sekreterlik yaptı. 2012 tarihinde Siyasal Bilgiler Fakültesi Dekanı olarak görev yapan Bozdoğan, 28 Ağustos 2015 tarihinde akademik işlerden sorumlu Rektör Yardımcısı olarak atandı.

Recep Bozdoğan, He graduated from Middle East Technical University, Department of Political Science and Public Administration in 1995. He received his master's degree and doctoral degree from Marmara University in the Department of Public Administration. He became assistant professor in 2002, associate professor in 2006 and professor in 2011. Between 2005 and 2006, he worked as a consultant in Istanbul Metropolitan Municipality; he served as Deputy Secretary in Istanbul Special Provincial Administration between 2006-2007 and as General Secretary in Marmara Municipal Union between 20072012. Bozdoğan, who served as the Dean of the Faculty of Political in 2012, was appointed as the Vice Rector responsible for academic affairs on 28 August 2015.

\section{Kaynakça Bilgisi / Citation Information}

Yılmaz, O. K. Ve Bozdoğan, R. (2018). Türkiye'de Belediyelerin Mevcut Kentsel Dönüşüm Uygulamalarına Yönelik Tutumları: İstanbul İlçe Belediyeleri Üzerine Bir Araştırma. IDEALKENT - Kent Araştırmaları Dergisi, 24, 430-455 